\title{
Hepatic granulomas in canine visceral leishmaniasis and clinical status
}

[Granulomas hepáticos na leishmaniose visceral canina e classificação clínica]

\author{
J.A.P. Sant'Ana ${ }^{1}$, W.G. Lima', M.R. Oliveira' ${ }^{2}$, L.A. Simões ${ }^{2}$, M.S.M. Michalick \\ M.N. Melo ${ }^{3}$, W.L. Tafuri ${ }^{3}$, Wg.L. Tafuri ${ }^{3}$ \\ ${ }^{1}$ Aluno de pós-graduação - FM-UFMG, Belo Horizonte, MG \\ ${ }^{2}$ Universidade Federal da Paraíba - João Pessoa, PB \\ ${ }^{3}$ Instituto de Ciências Biológicas - UFMG \\ Av. Antônio Carlos, 6627 \\ 31906-270 - Belo Horizonte - MG
}

\begin{abstract}
The histopathological description of intralobular hepatic granulomas in animals with a defined clinical status (asymptomatic, oligosymptomatic and symptomatic animals) was reported. Seventy-one mongrel dogs naturally infected with Leishmania chagasi were obtained from two Brazilian endemic areas: João Pessoa, PB and Belo Horizonte, MG. The hepatic parasite load was determined and compared to granuloma formation. Liver fragments from all infected animals showed remarkable leishmaniotic granulomatous inflammatory reaction. Granulomas with variable size were constituted by macrophages (parasitized or not with amastigotes of L. chagasi), some epithelioid cells, small numbers of lymphocytes, plasma cells, and rare neutrophils. Asymptomatic dogs had higher numbers of granulomas than oligosymptomatic and symptomatic animals from both geographical regions. However, the average diametric size of granulomas was very heterogeneous in all groups, independently of the geographic region $(\mathrm{P}>0.05)$. Parasite tissue load did not show any difference among liver fragments of all animals, especially when considering the defined clinical status and/or their geographic origin.
\end{abstract}

Keywords: dog, leishmaniasis, hepatic granuloma, clinical status

\section{RESUMO}

Descreve-se a formação de granulomas hepáticos na leishmaniose canina em animais com classificação clínica definida - assintomáticos, oligossintomáticos e sintomáticos. Setenta e um animais, sem raça definida e naturalmente infectados com Leishmania chagasi, foram obtidos de duas regiões endêmicas brasileiras: João Pessoa, PB e Belo Horizonte, MG. A carga parasitária tecidual foi determinada mediante emprego do Leishmania Donovani Units (LDU) e comparada com a formação de granulomas hepáticos. Fragmentos de figado de todos os animais infectados mostraram reação granulomatosa notadamente leishmaniótica. Granulomas de variáveis tamanhos eram constituidos por macrófagos, parasitados ou não com formas amastigotas de L. chagasi, algumas células epitelióides, pequeno número de linfócitos e plasmócitos, e raros neutrófilos. Cães assintomáticos apresentaram maior número de granulomas do que os animais oligossintomáticos e sintomáticos, em ambas as regiões geográficas. As médias dos diâmetros foram heterogêneas em todos os grupos, independente da região geográfica $(P>0,05)$. Quanto ao parasitismo (LDU), não houve diferença entre as amostras de figado, especialmente quando se consideraram a classificação clínica e a região geográfica.

Palavras-chave: cão, leishmaniose, granuloma hepático, classificação clínica

Recebido em 3 de agosto de 2006

Aceito em 13 de agosto de 2007

*Autor para correspondência (corresponding author)

E-mail: wagner@icb.ufmg.br

Financial support: CNPq (Proc. 477427/2006-5) 


\section{INTRODUCTION}

Human visceral leishmaniasis (HVL) and canine visceral leishmaniasis (CVL) in the New World are caused by Leishmania (Leishmania) chagasi, which is transmitted by the phlebotomine Lutzomyia longipalpis. L. chagasi belongs to Leishmania donovani complex, for example, $L$. chagasi in the New World, and L. donovani and Leishmania infantum in the Old World. The parasite exists in distinct morphologic forms in the hosts. The promastigote, a flagellated extracellular form, is found in the sand fly vector host, whereas the amastigotes, an unflagellated intracellular parasite, is commonly found in macrophages of mammalian host tissue (Grimaldi et al., 1989; Ashford, 2000).

In Brazil, CVL is highly endemic in many Northeastern states, as Maranhão, Piauí, Ceará, Rio Grande do Norte, Paraíba, Pernambuco and Bahia. There is an association between infected dogs and the abundance of Leishmania longipalpis in these states (Deane and Deane, 1962; Cunha et al., 1995; Ashford et al., 1998). Cunha et al. (1995) and Ashford et al. (1998) found an association between human infection and the presence of infected dogs in or near residences in the State of Bahia. Furthermore, visceral leishmaniasis (VL) appears to be spreading in Brazil and outbreaks have recently been reported in regions where the disease was previously unknown, e.g. in the city of Belo Horizonte, MG (Genaro et al., 1988; Michalick, 1993). Moreover, particularly alarming is the resurgence of epidemic VL in major Brazilian cities such as São Luiz, MA; Teresina, PI; Fortaleza, CE; João Pessoa, PB (Tafuri et al., 2001); and Rio de Janeiro, RJ (Marzochi et al., 1994).

L. chagasi and L. donovani, both visceralizing species, elicit granuloma formation in the livers of murine (Murray and Nathan, 1999) and canine hosts (Tafuri et al., 1996). This structure is a special cellular exudate mainly composed of mononuclear cells (monocytes-macrophages, lymphocytes and plasma cells). The structure of the mature granuloma induced by representative intracellular infection in experimental VL caused by $L$. donovani consists of a core of fused, parasitized resident macrophages with encircling mononuclear cell mantle containing blood monocytes and T cells (McElrath et al., 1988; Cervia et al., 1993; Murray and Nathan, 1999).

The antimicrobial efficacy of the granuloma response depends upon host and pathogen determinants. In addition, if the effector cell fails to become activated or is intrinsically deficient in a basic microbial mechanism, granuloma formation does not necessarily guarantee antimicrobial function. (Murray, 2001). Various authors have described the hepatic pathology caused by species of Leishmania (McElrath et al., 1988; Rallis et al., 2005). Up-to-the moment, little information exists in the literature about the association between clinical, pathogenetic and histopathological aspects of hepatic granulomas caused by L. chagasi in dogs. This work aimed to qualitatively and quantitatively study the hepatic granulomas in naturally infected dogs with L. chagasi in Belo Horizonte, MG and João Pessoa, PB. Additionally, associations between clinical status of the disease and the histopathological and parasitological features were investigated.

\section{MATERIAL AND METHODS}

Seventy-one mongrel dogs of unknown age naturally infected with $L$. chagasi were identified during an epidemiological survey of CVL carried out by the City Halls (Zoonosis Department) of João Pessoa, PB, (Brazil Northeastern) and Belo Horizonte, MG, (Brazil Southeastern). The used tests were indirect immunofluorescence antibody titles (IFAT), complement fixation reaction (CFR), and enzyme-linked immunosorbent assay (ELISA) (Andrade et al., 2002). Immunofluorescent titles ( $>1: 40$ dilutions), CFR $(>1: 40$ dilutions) and ELISA (optical density $>100 ;>1: 400$ dilutions) were positive for all animals. In addition, it was used a test with a commercial kit containing an immunochromatographic strip that uses recombinant leishmanial antigen $\mathrm{k} 39$; a dominant amastigote antigen of $L$. (L.) chagasi (rK39), which is highly sensitive and specific for $L$. donovani complex infection, as previously described (Sundar et al., 2002). Sera from all infected dogs were also positive for this test. 
Animals were divided into three groups: group I consisted of 18 naturally infected dogs from João Pessoa, PB; group II consisted of 53 naturally infected dogs from Belo Horizonte, MG; and group III consisted of five uninfected animals (control animals) - two from João Pessoa, PB, and three from Belo Horizonte, MG. These control animals were serologically and parasitologically negative for Leishmania infection.

All infected dogs were clinically classified according to a previously reported study (Mancianti et al., 1998), as follows: symptomatic - animals that exhibited the classical signs of the disease, such as, cutaneous alterations (alopecia, dry exfoliative dermatitis or ulcers), onychogryphosis, keratoconjunctivitis, cachexia and anemia; oligosymptomatic - animals exhibiting clinical signs of the disease and/or lesions such as lymphoid lymphadenopathy, moderate weight loss and/or dull brittle fur accompanied by cutaneous lesions; and asymptomatic - apparently healthy animals.

Animals from João Pessoa, PB were divided into three groups of six symptomatic, six oligosymptomatic and six asymptomatic dogs. Animals from Belo Horizonte, MG were divided into three groups of 19 symptomatic, 20 oligosymptomatic and 14 asymptomatic dogs.

Dogs were sacrificed with a lethal dose $(1 \mathrm{ml} / \mathrm{kg})$ of Thiopental ${ }^{\circledR}$ sodic and $\mathrm{T} 61^{\circledR}(0.3 \mathrm{ml} / \mathrm{kg} \mathrm{IV})$. Samples of liver were collected and fixed in a $10 \%$ neutrally buffered formalin solution. All tissue samples were dehydrated, cleared, embedded in paraffin, cut into 4-5 $\mu \mathrm{m}$ thick sections, and stained with hematoxylin and eosin (HE). Others samples of liver and spleen were used for parasitological analysis, fixed with methanol and stained with Giemsa solution. This assay was used to confirm the diagnosis of CVL. Amastigote forms of Leishmania could be observed inside macrophages of livers and spleens of all animals by light microscopy using immersion oil (objective 100X).

Paraffined liver tissue sections were subjected to Leishmania amastigotes immunohistochemical identification according to the Tafuri et al. (2004) method. Deparaffined slides were hydrated and incubated in $4 \% 30 \mathrm{vv}$ hydrogen peroxidase in $0.01 \mathrm{M}$ PBS, $\mathrm{pH} 7.2$ to block endogenous peroxidase activity, followed by incubation with normal goat serum (1/100 dilution) to block nonspecific immunoglobulin absorption to tissues. A heterologous hyperimmune serum from one dog naturally infected with $L$. (L.) chagasi (IFTA; title $\geq 1: 40$ ), diluted $1: 100$ in $0.01 \mathrm{M}$ PBS was used as primary antibody. Slides were incubated from 18 to $22 \mathrm{~h}$ at $4^{\circ} \mathrm{C}$ in a humid chamber. After washing in PBS, the slides were incubated with biotinylated goat anti-mouse and anti-rabbit ${ }^{1}$, washed in PBS again, and then incubated with the streptavidinperoxidase complex ${ }^{2}$ for $20 \mathrm{~min}$ at room temperature. The reaction was developed with a $0.024 \%$ diaminobenzidine ${ }^{3}$ solution and $0.16 \%$ $40 \mathrm{vv}$ hydrogen peroxidase. Finally, slides were dehydrated, cleared, counter-stained with Harris'Hematoxylin, and mounted with coverlips.

The liver parasite burden was expressed as Leishman-Donovan Units (LDU) (Stauber, 1956). The LDU index was determined by microscopic enumeration of Leishmania amastigotes divided by 1000 cell nuclei and the result was multiplied by the organ weight.

The number of granulomas was determined with quantification of twenty microscope optic fields using a 40X objective of an Axiolab light microscope (Zeiss). The images, viewed on a computer video screen, were obtained by means of the software and relayed to a computer-assisted image analysis system ${ }^{4}$. Using a digital pad, the total diameter of granulomas was measured and the results were expressed in squared micrometers (Caliari, 1997).

The software Instat for Windows was used for the descriptive analysis and inferences. LDU and histological data were statistically analyzed by the non-parametric Kruskal-Wallis test (Sampaio, 1998).

\section{RESULTS}

The main clinical features of all animals are presented in Table 1. Skin abnormalities were the most common manifestation of CVL. In fact, the principal clinical sign was a chronic ulceration primarily localized to the ears and limbs, followed

${ }^{1}$ Link-DAKO, LSAB2 Kit, catalog \# KO675-1; Carpinteria, California USA.

${ }^{2}$ DAKO, LSAB2 Kit, Catalog \# K0675-1; Carpinteria, California, USA

${ }^{3} \mathrm{DAB}$; Sigma, St. Louis, USA.

${ }^{4}$ Kontron Electronic/Carl Zeiss, Germany. 
by onychogryphosis and dry desquamation. The second major clinical sign was generalized

lymphadenopathy.

Table 1. Clinical features and lesions frequency of naturally infected dogs with Leishmania (L.) chagasi from João Pessoa, PB and Belo Horizonte, MG

\begin{tabular}{lcc}
$\begin{array}{l}\text { Clinical features } \\
\text { and lesions }\end{array}$ & $\begin{array}{c}\text { Number of dogs in João Pessoa, } \\
\text { PB/ lesions frequency }\end{array}$ & $\begin{array}{c}\text { Number of dogs in Belo Horizonte, } \\
\text { MG/ lesions frequency }\end{array}$ \\
\hline Lymphadenopathy & $9(42.8 \%)$ & $15(28.3 \%)$ \\
Alopecia & $2(9.5 \%)$ & $11(19.6 \%)$ \\
Dry desquamation & $1(4.8 \%)$ & $2(3.78 \%)$ \\
Onychogryphosis & $7(33.3 \%)$ & $8(15 \%)$ \\
Skin ulceration & $13(62 \%)$ & $20(37.7 \%)$ \\
Cachexia & $3(14.5 \%)$ & $1(1.9 \%)$ \\
Anemia & $2(9.5 \%)$ & $5(9.4 \%)$ \\
\hline
\end{tabular}

Microscopically, histological analysis by $\mathrm{HE}$ showed a general chronic inflammatory reaction involving the entire architecture of the liver including the capsule (Fig. 1A), portal tracts (Fig. 1B), and central veins, or perisinusoidal spaces. Other common observed lesions were hypertrophic and hyperplastic Kupffer cells loaded with amastigotes and intense congestion of the sinusoid vessels (Fig. 1C). However, liver fragments from all infected animals showed a remarkable leishmaniotic granulomatous inflammatory reaction. There were many intralobular hepatic granuloma formations with variable size constituted by macrophages (parasitized or not with amastigotes of $L$. chagasi), some epithelioid cells, small numbers of lymphocytes, plasma cells, and rare neutrophils (Fig. 1D). Multinucleated giant cells were not observed in the hepatic granulomas. The granulomas were rarely confluent and localized to the sinusoid lumen (total or partial occlusion) and around the portal vessels. Pigments were detected as brown crystals (hemosiderin) and were chiefly localized to Kupffer cells and macrophages within granulomas. Amastigotes forms of Leishmania could be observed inside macrophages of the intralobular granulomas (Fig. 1E). By immunohistochemical analysis, Leishmania amastigotes forms were observed in macrophages mainly localized to the intralobular granuloma center (Fig. 1F), in the sinusoidal capillaries (Kupffer cells), and in the portal triads. In general, the hepatic lobules were preserved, but the hepatocytes around the granulomas were atrophic, because of compression.

Asymptomatic dogs had higher numbers of granulomas than oligosymptomatic and symptomatic animals from both geographical regions. However, the average diametric size of granulomas was very heterogeneous in all groups, independently of the geographic region $(\mathrm{P}>0.05)$. Interestingly, the hepatic granulomas of animals from João Pessoa, PB were higher than animals from Belo Horizonte, MG (Table 2). There was no statistical difference among the number or size of granulomas when considering the defined clinical status of the animals and/or their geographic origin.

The LDU results are depicted in Table 3 . Statistical analysis of LDU data did not show any difference in parasite burden among liver fragments, especially when considering the defined clinical status of the animals and/or their geographic origin. However, the tissue parasitism (LDU) was variable. The hepatic samples of Belo Horizonte, MG dogs showed higher LDU numbers in comparison with the dogs from João Pessoa, PB. 

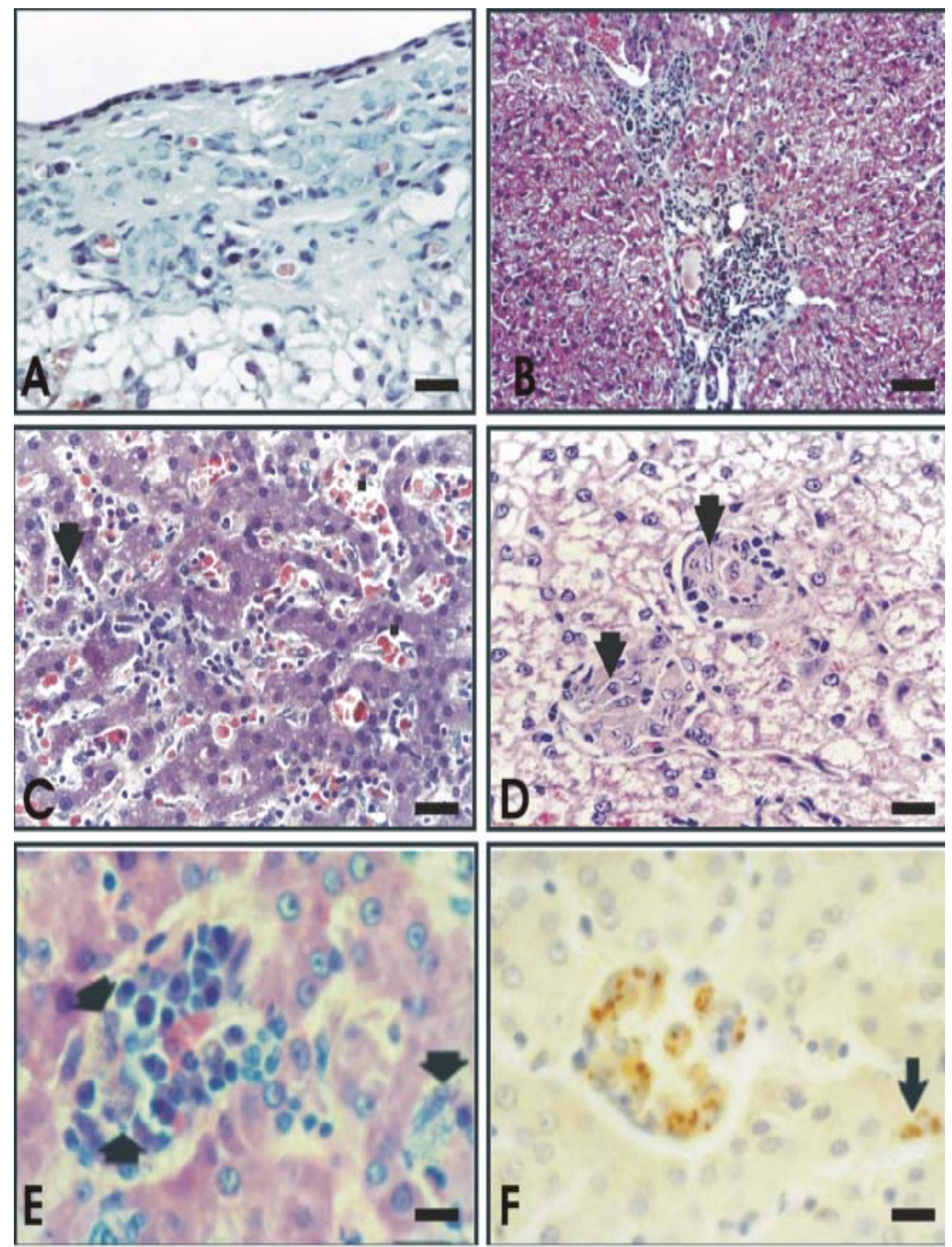

Figure 1. (A-F): Liver sections of dogs naturally infected with $L$. (L) chagasi. (A) a chronic inflammatory reaction in the Glisson capsule 220x.HE (B) inflammatory chronic reaction in portal tract 110x HE. (C) hypertrophy and hyperplasia of Kupffer cells (arrows) and congestion (arrowheads). 440xHE. (D) hepatic granuloma intralobular formation comprising epithelioid cells (arrow), plasmocytes and lymphocytes. 440xHE. (E,F) HE and immunohistochemistry showing on the left amastigotes within granuloma macrophages and on the right a Kupffer cell (arrow). Streptavidin-biotin peroxidase complex method, 440x. 
Table 2 Averages of the hepatic granulomas area $\left(\mu \mathrm{m}^{2}\right)$ observed in dogs naturally infected with Leishmania (L.) chagasi from João Pessoa, PB and Belo Horizonte, MG

\begin{tabular}{lcc}
\multicolumn{1}{c}{ Animal clinical status } & João Pessoa, PB dogs & Belo Horizonte, MG dogs \\
\hline Symptomatic & $4263.03 \pm 5604.54 \mathrm{a}$ & $2201.74 \pm 4254.51 \mathrm{a}$ \\
Oligosymptomatic & $5294.19 \pm 5931.52 \mathrm{a}$ & $2649.03 \pm 5182.39 \mathrm{a}$ \\
Asymptomatic & $9567.83 \pm 9955.11 \mathrm{a}$ & $1183.24 \pm 2194.78 \mathrm{a}$ \\
\hline
\end{tabular}

Averages followed of equal letters, in the same column, indicate no statistical difference $(\mathrm{P}>0.05)$

Table 3. Average amounts of Leishman Donovan Units in the livers of dogs naturally infected with Leishmania. (L.) chagasi from João Pessoa, PB and Belo Horizonte, MG

\begin{tabular}{lcc}
\multicolumn{1}{c}{ Animal clinical status } & João Pessoa, PB dogs & Belo Horizonte, MG dogs \\
\hline Symptomatic & $1.81 \pm 1.14 \mathrm{a}$ & $9.62 \pm 24.15 \mathrm{a}$ \\
Oligosymptomatic & $0.81 \pm 1.25 \mathrm{a}$ & $3.43 \pm 6.83 \mathrm{a}$ \\
Asymptomatic & $1.65 \pm 0.6 \mathrm{a}$ & $18.53 \pm 50.9 \mathrm{a}$ \\
\hline
\end{tabular}

Averages followed of equal letters, in the same column, indicate no statistical difference $(\mathrm{P}>0.05)$

\section{DISCUSSION}

CLV is an endemic disease in Brazil and dogs represent the principal domestic reservoir of L.chagasi. These animals play a central role in the transmission cycle to humans by phlebotomine sand flies. As also observed in the Old World (Ciaramella et al., 1997), symptomatic cases of CVL due to L. chagasi, in America, presents clinically with anemia, emaciation, splenomegaly, local or generalized lymphadenopathy, cutaneous lesions, ocular lesions (Brito et al., 2006) weight loss, and cachexia. In the present study, dermatological entities previously described by Ferrer (1988), Ciaramella et al. (1997) and Lima et al. (2004) were observed. Dry desquamation associated with alopecia usually starting on the head (mainly ears and eyes-orbital) and extending to the rest of the body was observed (Ferrer 1988; Ciaramella et al., 1997). In the L. infantum infection, Rallis et al. (2005) also noted nasodigital hyperkeratosis and bacterial, superficial or deep pyoderma. Lymphadenopathy was detected in many cases (Table 1). According to the literature, skin lesions are a more significant than lymphadenopathy. Similar results were obtained for Lima et al. (2004) and Rallis et al. (2005).

In this study, the major hepatic lesion observed in association with L. chagasi parasitism was intralobular granuloma, as described for Genaro (1993), Oliveira et al. (1993), Tafuri et al. (1996), Tafuri et al. (2001) and Xavier et al. (2006). This lesion also was noted in HVL and experimental models of the disease (Gonzalez et al., 1988; El Hag et al., 1994). On the other hand, Rallis et al. (2005) observed granulomatous to pyogranulomatous foci containing macrophages, lymphocytes and plasma cells infiltration, especially in the portal areas. In this study, intralobular granulomas constituted by macrophages (parasitized or not with amastigotes of L. chagasi), some epithelioid cells, small numbers of lymphocytes, plasma cells and rare neutrophils were found. Thus, pyogranulomatous lesions as described by Rallis et al. (2005) were not observed.

Intracellular infections associated with granulomatous inflammation include those caused by mycobacteria, select fungi and bacteria, and certain protozoa such as Leishmania species (Willians and Willians, 1983; Scheffield, 1990; Murray and Nathan, 1999). According to Murray (2001), an immunologically active (epithelioid-type) granuloma is required for functional antimicrobial action. These cells are recruited along with immigrant blood monocytes and take up residence closely to or in the mononuclear mantle, which slowly evolves to surround and/or infiltrate the core of infected macrophages. In some instances, B cells, plasma cells, some neutrophils and/or eosinophils are also attracted. In fact, in the present investigation, epithelioidtype granulomas with this histological definition were found in all cases, even when accounting for defined clinical status of the animals and/or their geographic origin. In the murine experimental VL caused by $L$. donovani, the 
structure of the mature granuloma induced by representative intracellular infection consisted of a core of fused, parasitized resident macrophages with an encircling mononuclear cell mantle containing blood monocytes and T cells (Murray and Nathan, 1999).

According to many authors, granulomas represent a successful $\mathrm{T}$ cell-dependent immune response (Sheffield 1990; Murray and Nathan, 1999; Hernandez-Pando et al., 2000). Granulomas typically require an antigen-specific immune response mediated by mononuclear cells, develop relatively slow and persist for extended periods, and are more likely to be provoked by intra rather than extracellular pathogens (McElrath et al., 1988). In leishmaniasis, similar to other diseases caused by intracellular parasites, cellular immune responses are paramount in determining healing or resistance to disease in human or murine hosts (Kaye et al., 2004). In HVL, for example, the presence of granulomas in the liver appears to correlate with spontaneous control and maintenance infections in a subclinical state (Murray, 2001). However, the antimicrobial efficacy of the granulomatous response seems to be imprecise and depends upon host and pathogens determinants. In other words, granuloma formation does not necessarily guarantee antimicrobial function if the effector cell fails to become activated or is intrinsically deficient in a basic microbial mechanism (Murray, 2001).

Thus, in the present work, any correlation between the number or size of the hepatic granulomas and the clinical animal status and parasite load was not found. Rallis et al. (2005) also did not observe an association between histopathological lesions, the clinical signs of CVL or the amastigote load within the liver tissue. Futures investigations are necessary to better define the relationship between granulomatous hepatic lesions and CVL.

\section{REFERENCES}

ASHFORD, R.W. The leishmaniases as emerging and reemerging zoonoses. Int. J. Parasitol., v.30, p.1269-1281, 2000.

ASHFORD, D.A.; DAVID J.R.; FREIRE, M. et al. Studies on control of visceral leishmaniasis: impact of dog control on canine and human visceral leishmaniasis in Jacobina, Bahia, Brazil. Am. J. Trop. Med. Hyg., v.59, p.53-57, 1998.

BRITO, F.L.C.; ALVES, L.C.; MAIA, F.C.L. et al. Ocular alterations in dogs naturally infected by Leishmania (Leishmania) chagasi. Arq. Bras. Med. Vet., v.58, p.768-775, 2006.

CALIARI, M.V. (Ed.) Princípios de morfometria digital: KS300 para iniciantes. Belo Horizonte: Editora UFMG, 1997. 149p.

CERVIA, J.S.; ROSEN, H.; MURRAY, H.W. Effector role of blood monocytes in experimental visceral leishmaniasis. Infect. Immunity, v.61, p.1330-1333, 1993.

CIARAMELLA, P.; OLIVA G.; LUNA, R.D. et al. A retrospective clinical study of canine leishmaniasis in 150 dogs naturally infected by Leishmania infantum. Vet. Rec., v.141, p.539543, 1997.

CUNHA, S.; FREIRE, M.; EULALIO, C. et al. Visceral leishmaniasis in a new ecological niche near a major metropolitan area of Brazil. Trans. R. Soc. Trop. Med. Hyg., v.89, p.155-158, 1995.

DEANE, L. M.; DEANE, M. P. Visceral leishmaniasis in Brazil: geographical distribution and transmission. Rev. Inst. Med. Trop. São Paulo, v.4, p.198-212, 1962.

EL HAG, I.A.; HASHIM, F.A.; EL TOUM, I.A. et al. Liver morphology and function in visceral leishmaniasis (Kala-azar). J. Clin. Pathol., v.47, p.547-551, 1994.

FERRER, L. Skin lesions in canine leishmaniasis. J. Small Anim. Pract., v.29, p.381388, 1988.

GENARO O.; MAYRINK, W.; MICHALICK, M.S.M. et al. Naturally occurring visceral leishmaniasis in dogs: clinical aspects. Mem. Inst. Oswaldo Cruz., v.83, p.43, 1988.

GENARO, O. Leishmaniose visceral canina experimental. 1993. 220f. Tese (Doutorado em Parasitologia) - Instituto de Ciências Biológicas, Universidade Federal de Minas Gerais, Belo Horizonte.

GONZALEZ, J.L.; ROLLAN, E.; NOVOA, C. et al. Structural and ultrastructural hepatic changes in experimental canine leishmaniasis. Histol. Histopathol., v.3, p.323-329, 1988. 
GRIMALDI Jr., G.; TESH, R.B.; McMAHONPRATT, D. A review of the geographic distribution and epidemiology of leishmaniasis in the New World. Am. J. Trop. Med. Hyg. v.41, p.687-725, 1989.

HERNANDEZ-PANDO, R.; BORNSTEIN, Q.L.; AGUILAR LEON, D. et al. Inflammatory cytokine production by immunological and foreign body multinucleated giant cells. Immunology, v.100, p.352-358, 2000.

KAYE, P.M.; SVENSSON, M.; ATO, M. et al. The immunopathology of experimental visceral leishmaniasis. Immunol. Rev., v.201, p.239-253, 2004.

LIMA, W.G.; MICHALICKM, S.M.; MELO, M.N. et al. Canine Visceral Leishmaniasis: a histopathological study of lymph nodes. Acta Tropica., v.92, p.43-53, 2004.

MANCIANTI, F.; GRAMICCIA, M.; GRADONI, L. et al. Studies on canine leishmaniasis control. I. Evolution of infection of different clinical forms of canine leishmaniasis following antimonial treatment. Trans. R. Soc. Trop. Med. Hyg., v.82, p.566-567, 1998.

MARZOCHI, M.C.; MARZOCI, K.B.F.; CARVALHO, R.W. Visceral Leishmaniasis in Rio de Janeiro. Parasitol. Today, v.10, p.37-40, 1994.

McELRATH, M. J.; MURRAY, H.W.; COHN, $Z$. A. The dynamics of granuloma formation in experimental visceral leishmaniasis. J. Exp. Med., v.167, p.1927-1937, 1988.

MICHALICK, M.S.M. Spreading of visceral leishmaniasis in urban area of Belo Horizonte, MG, Brazil. Mem. Inst. Oswaldo Cruz, v.88, supl.I, p.53, 1993.

MURRAY, H.W.; NATHAN, C.F. Macrophage microbicidal mechanisms in vivo: reactive nitrogen vs oxygen intermediates in the killing of intracellular visceral Leishmania donovani. J. Exp. Med., v.189, p.741-746, 1999.

MURRAY, H. W. Tissue granuloma structurefunction in experimental visceral leishmaniasis. Int. J. Exp. Pathol., v.82, p.249-267, 2001.

OLIVEIRA, G.G.S.; SANTORO, F.; SADIGURSKY, M. The subclinical form of experimental visceral leishmaniasis in dogs. Mem. Inst. Oswaldo Cruz, v.88, p.243-248, 1993.
RALLIS, T.; $\quad$ DAY, M.J.; SARIDOMICHELAKIS, M.N. et al. Chronic hepatitis associated with Canine Leishmaniosis (Leishmania infantum): a clinicopathological study of 26 cases. J. Comp. Pathol., v.132, p.145-152, 2005.

SAMPAIO, I.B.M. Estatística aplicada à experimentação animal. Belo Horizonte: FEPMVZ, 1998. 221p.

SHEFFIELD, E.A. The granulomatous inflammatory response. J. Pathol., v.160, p.1-2, 1990.

STAUBER, L.A. Host resistance to the Kharthoum strain of Leishmania donovani. Rice Inst. Pamphlet, v.45, p.80-96, 1956.

SUNDAR, S.; PAI, K.; SAHU, M. et al. Immunochromatographic strip-test detection of anti-K39 antibody in Indian visceral leishmaniasis. Ann. Trop. Med. Parasitol., v.96, p.19-23, 2002.

TAFURI, Wg. L.; TAFURI, W.L.; BARBOSA, A.J.A. et al. Histopathology and immunocytochemical study of type 3 and type 4 complement receptors in the liver and spleen of dogs naturally and experimentally infected with Leishmania (Leishmania) chagasi. Rev. Inst. Med. Trop. São Paulo, v.38, p.81-89, 1996.

TAFURI, Wg. L.; OLIVEIRA, M.R.; MELO, M.N. et al. Canine Visceral Leishmaniosis: a remarkable histopathological picture of one case reported from Brazil. Vet. Parasitol., v.2, p.203212, 2001.

TAFURI, Wg.L.; SANTOS, R.L.; ARANTES, R.M.E. et al. An alternative immunohistochemical method for detecting Leishmania amastigotes in paraffin-embedded canine tissues. J. Immunol. Meth., v.292, p.1723,2004

WILLIAMS, G.T.; WILLIAMS, W.J. Granulomatous inflammation - a review. J. Clin. Pathol., v.36, p.723-733, 1983.

XAVIER, S.C.; CHIARELLI, I.M.; LIMA, W.G. et al. Canine visceral leishmaniasis: a remarkable histopathological picture of one asymptomatic animal reported from Belo Horizonte, Minas Gerais, Brazil. Arq. Bras. Med. Vet. Zootec., v.58, p.994-1000, 2006. 